\title{
Learning Environments as Basis for Cognitive Achievements of Students in Basic Science Classrooms in Nigeria
}

\author{
Atomatofa Rachel ${ }^{1, *}$, Okoye Nnamdi ${ }^{2}$, Igwebuike Thomas ${ }^{3}$ \\ ${ }^{1}$ Department of Integrated-Science, Delta State College of Physical Education, Nigeria \\ ${ }^{2}$ Department of Curriculum and Integrated-science, Delta State University, Nigeria \\ ${ }^{3}$ Department of Curriculum Studies, College of Education Warri, Nigeria
}

Copyright $\subseteq 2016$ by authors, all rights reserved. Authors agree that this article remains permanently open access under the terms of the Creative Commons Attribution License 4.0 International License

\begin{abstract}
The nature of classroom learning environments created by teachers had been considered very important for learning to take place effectively. This study investigated the effect of creating constructivist and transmissive learning environments on achievements of science students' of different ability levels. 243 students formed the entire study sample, while 146 (70 high and 76 low ability) students took part in the ability groupings. Three research instruments (teaching guides; scholastic ability test and Basic science achievement test), were used to obtain data for which two research hypotheses were tested. The validation and reliability of the instruments were fully established. Results indicate that students in the constructivist environment achieved more. And that the high ability students irrespective of their learning environment achieved more than the low ability students which indicates that learning environments do not have impact on learning ability. However, since the high and low constructivist groups achieved more than the high and low transmissive groups respectively, it is recommended that teachers should create the constructivist environment while paying extra attention to the low ability groups in order to reduce gaps between high and low ability during their basic science classes in Nigeria.
\end{abstract}

Keywords Learning Environments, Constructivist Environment, Transmissive Environment

\section{Introduction}

Acquiring basic scientific knowledge has become very important around the globe especially in developing countries like Nigeria. This calls for adequate preparation of science teachers. One factor recently being investigated by science education researchers, responsible for students' gaining of knowledge, is the nature of the learning environment created by the teacher. Federal Government of Nigeria (1) stated that "no educational standard can rise above the quality of the teachers". This means that students' achievement is greatly affected by how they are taught by their teachers. Teachers do create learning environment depending on how they perceive their roles, organize their teaching and the instructional method used.

Researchers in the last 30 years have been able to show the relationship between the classroom learning environments created by teachers, instructional strategies as well as social interactions between the teachers and students. Classroom learning environments created by teachers have been found to have a considerable impact on the students' achievement of science. (2-5). The environment can hinder or facilitate the development of individual student's active and creative abilities hence researchers have started studying the child's learning environment (6-7).

According to (8), studies on students' achievement in Nigeria have been focused on students' characteristics and school curriculum but these two factors alone cannot determine students' achievement in learning. The nature of the learning environments and their interactions with other variables has been considered very important for learning to take place (2). This nature of learning environment according to Igwebuike (2) has not been widely emphasized in Nigeria, as a developing country. Also, a positive interactive learning environment is more important in predicting students' achievements than "hard to change" factors like class size availability of instructional materials and teachers years of experience. Kaufman (9) found out that a good relationship between teachers and students in elementary and high schools strongly predicted gains in Mathematics. He concluded that classroom learning environment needs to be nurturing while holding students to high academic standards.

The classroom learning environments created by the 
teachers are predictor variables that have shown consistent relationships with the learner's cognitive and affective outcomes (10). Therefore it is important for teachers to consider and assess the learning environment they create as it affects learning outcomes needs. (11). Depending on what the teacher wants, the participatory structure of the class can be either teacher-centred or learner-centred. Teachers who use high quality instructional strategies appropriate to students' educational needs create opportunities for thinking and analysis as they update students' prior knowledge. Kaufman (9) discovered that teachers, who use more learner-centred practices such as the constructivist strategies involving students, produce greater motivation and academic improvement than those who use more of teacher centerd approaches like the transmissive or lecture methods. Also, teachers who use instructional strategy that foster positive relationship with their students, create classrooms that are more conducive to learning and meets students' academic needs. Quite a number of researchers have proved that the learning environment has great positive impact on students' academic achievement and that there is a significant relationship between classroom learning environment and students learning outcomes $(2,12-20)$

Transmissive methods are teacher- centred methods where lots of teacher-centred activities go on in the class. Among the transmissive methods is the lecture method, where the teacher is the main actor while the students are passive learners. The classroom climate is described by many as non-stimulating and boring, deadens creativity and practicality, and emphasizes rote memorization of concepts and robbing the students the opportunity to think for themselves (21-24). However in spite of its shortcomings, the lecture methods have been seen to be effective in teaching scientific concepts to students. $(8,22,25)$.

On ability groups, some studies show that poor instructional strategies and learning environments have impact on learning ability. Turner, Midgley, Gheen et al (26) found out that poor performances of low ability group in sciences was due to the inappropriate instructional strategy used and poor learning environments created by the teachers. Researchers found out that students ability levels can be used to predict their cognitive achievement from instruction. Nigerian classrooms are composed of students of different academic ability levels, hence ability groups should be considered when carrying out any research on academic achievement in Nigeria. $(8,27)$.

This study compared the achievement of students of different cognitive abilities taught in a constructivist and transmissive classroom learning environment in Nigeria. Researches carried out by Aldridge, Fraser \& Laugksch, (28), shows that till the year 2011, few researches have been carried out to help teachers access and improve their classroom learning environment. Having observed from the results of previous studies that students' achievements in basic-science had been poor and that learning environment is one factor responsible for this, it became necessary for this research where a constructivist and a transmissive learning environment were created to compare the achievement of the students taught in the different environments. Specifically, this study was to find out which of the constructivist or transmissive learning environment will enable students of different ability levels acquire more basic science contents. It is hoped that the results of this study will be useful for policy makers in education to guide basic science teachers on the best learning environment to create for students to acquire more knowledge of basic science.

To guide this study, two research questions and two hypotheses were stated.

\subsection{Research Questions}

- What difference exists in achievement test of students taught basic science in a constructivist learning environment and those taught in a transmissive learning environment?

- Is there any difference in basic science achievement test scores of high ability students and low ability students exposed to a constructivist learning environment and transmissive learning environment?

\subsection{Research Hypotheses}

- There is no significant difference in achievement test of students taught basic science in a constructivist and in a transmissive learning environment.

- There is no significant difference in achievement test of high ability and low ability students taught basic science in a constructivist and a transmissive learning environment.

\section{Materials and Methods}

\subsection{General Background of Research}

The setting for the study is six intact classes with a sample of 243 students across the three senatorial districts of Delta State, Nigeria. Three of the classes with a total of 122 students served as constructivist group where students were tutored in a constructivist learning environment while the other three classes with a total of 121 students served as transmissive group where students were taught in a transmissive or convention learning environment.

The Research Instruments used were the Teaching guides consisting of Basic science content materials used in preparing the constructivists lessons as well as the transmissive lessons and the two Evaluation packages consisting of the Basic Science Scholastic Ability Test (BSSAT) and Basic Science Achievement Test (BSACT).

\subsection{Teaching Guides (Basic science content materials):}

The teaching guides have as contents the following 


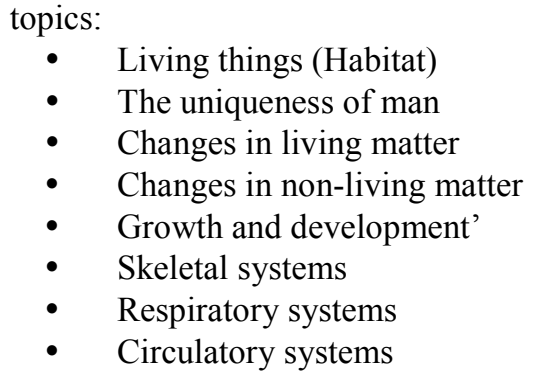

The content was the same for the constructivist and transmissive groups but the presentation was different depending on the learning environments whether teacher or student- centred environment. The Constructivist groups used the constructivist strategy where the teacher created a learner-friendly learning environment. The transmissive groups used the transmissive strategy where the teacher created a teacher-centred learning environment. In order to control for any possible experimental bias the researcher was not involved in the teaching or administration of test items although all materials were prepared by researcher. The teachers for the various learning environments were personally trained by the researcher for 2 weeks before the study.

The teaching guides were developed by the researcher from the concepts' contained in the newly approved Basic Science textbook. While the test questions (BSACT) was selected from past junior certificate exams questions of Delta state ministry of education that are related to the chosen topics. The workbook for the Basic Science text book approved by Federal Ministry of Education was also used in constructing the content as well as test questions. The BSACT which consist of 40 objectives questions were administered as pre-test before the commencement of the treatment exercise and re-arranged and used as post-test after the treatment sessions. It covered all the topics treated and is the same for all the groups.

The BSSAT consist of 30 questions carefully drawn from the Junior Secondary one first, second and third term exams questions of the Delta State Ministry of Education. It was given to the students in all the groups before the treatment to test their general knowledge of science. It was also used to differentiate between ability levels of students in all the groups.

\subsection{Validity of Instruments}

The instruments Teaching guides(Basic Science Content materials), Basic Science Achievement Test (BSACT) and Basic Science Scholastic Ability Test (BSSAT) were subjected to face validities by two measurement and evaluation experts and a senior Basic science teacher with about 7 years' experience in teaching the subject. The experts examined the questions to see if they could be used to answer the research questions and also test the hypotheses. They also check if the test measured clearly what they intend to measure. For the content validity of
BSACT, a table of specification was used and the comments of the experts were used to produce the final draft for the study.

\subsection{Reliability of Test Instruments}

To establish the reliability of BSACT, a pilot study was carried out on 30 junior secondary three students who have just completed the Junior Secondary two syllabuses containing the topics to be used in this research. Using the Kuder Richerson 21 formula, reliability co-efficient of 0.82 was obtained.

In order to establish a reliability of the BSSAT items a pilot test was carried out on 30 Junior Secondary two students in a school which is not part of the schools for the study but had similarities with the schools used for the study. The Kuder-Richardson 21 reliability co-efficient shows the result of the standardized items as 0.70 .

\subsection{Training of Research Assistants/ Procedure for Experiments/ Data Collection}

On training of research assistants for data collection, 6 research assistants, three for each of the two groups were trained by the researcher two weeks before commencement of the exercise. They were taught how to create the learning environment for their respective groups and were given the teaching guides and content materials relevant to them as well as the procedure for each of the environment. They were taught how to administer and collect the ability test, pretests and posttests materials.

The (BSSAT), consisting of 30 objective questions were administered to the subjects in the entire group by the trained research assistants during the two weeks before the treatment session began. The results were collected the same day and used to categorize students into high and low ability. The middle ability was not used in this research.

The pretest of BSACT consisting of 40 objective questions were given to subjects in both groups by the trained research assistants two weeks before the treatment sessions began. The results were collected the same by the trained research assistants and given to the researcher for data analysis.

Two weeks after the pretest, the students were taught the 16 lessons of 45 minutes each in 8 weeks meaning 2 lessons per week. At the end of the lessons, the posttest for the BSACT was administered. The constructivist classroom learning environment was friendly, co-operating and stimulating which are features of the social constructivist environment.

Below is the format for presentation in the constructivist learning environment for all lessons.

\section{Lesson presentation format for all constructivist classes (45mins for each lesson)}

Step 1: (5mins): Teacher revised previous lesson and introduced the lesson for the day; divide students into groups 
of 8-10 for the various activities based on the objectives of the lessons.

Step 2: (8mins): Each group was given activities to do and materials to use, based on the objectives of the lesson. Students engaged in explorations and sharing of ideas; they discover ideas and record their observation and findings. Teacher moved from group to group, explaining, asking and answering questions students asked.

Step 3: (8mins): Groups reconvened and students begun discussions based on findings from each group while the teacher facilitated.

Step4: (7mins): Teacher elaborated on students' ideas, gave correct concepts over students' misconceptions and gave scientific explanations for correct concepts.

Step 5: (7mins): The major concepts in the lesson were further developed by the teacher taking note of the objectives of the lesson. The students were allowed to ask questions and take down notes.

Step6: (10mins): Teacher determined if behavioral objectives were attained by evaluating students. Chalkboard summary were given to students. Finally students were given assignments to read up and do before the next topic.

\section{The transmissive learning environment was mainly teacher centred.}

Format for presentation for all the lessons in the transmissive environment:

Step 1: $5 \mathrm{mins}$ Routine and revision of previous knowledge as well as introduction of new lesson by teacher.

Step 2:20min Teacher presents lesson step by step following strictly the objectives of the lesson; students listens and observe and where needed, they assist teacher to demonstrate.

Step 3:5mins Teacher gives students room to ask and answer questions arising from the lesson.

Step 4: 5 mins Teacher summarizes and reinstate salient points.

Step 5: 5mins Teacher evaluates (questions or assignment)

Step 6: 5mins Teacher gives chalkboard summary.

\subsection{Analytical Frameworks}

Data collected from Basic science achievement test
(BSACT) were analyzed using descriptive statistics showing means and standard deviation to answer the research questions, t-testing to show significant difference; and simple descriptive statistics were used get the statistics of science teachers that have been trained on to create a constructivist learning environment, and the fraction that apply the knowledge during science lessons.

Data from the Basic Science Aptitude Test (BSSAT) were collected and used to categorize students into the high and low ability. Those who score $60 \%$ and above were rated under the high ability while those who score below $40 \%$ as low ability in the two groups. The middle group who fall between $40 \%$ and $59 \%$ was not be used because of the tendency for them to fall into either of the high or low group with the slightest change. At the end only 146 students were used in the test of hypothesis two. Of the 146 students, 54 students ( 26 constructivist and 28 transmissive) fell into the high ability group; while 92 students (44 constructivist and 48 transmissive) fell into the low ability group. The remaining 97 students (52 constructivist and 45 transmissive) fell into the middle ability group and were not part of the data for hypothesis two.

\section{Findings}

\subsection{Research Question One}

What difference exists in achievement test of students taught basic science in a Constructivist learning environment and those taught in a transmissive learning environment?

Table 1 Shows that there are differences in basic science achievement test scores between students exposed to a constructivist learning environment and those exposed to a transmissive learning environment. The constructivist learning environment group had pretest and posttest means of 14.33 and 24.60 respectively while the transmissive learning environment group had pretest and posttest mean of 14.37 and 22.19 respectively. The difference between the post -test and pre-test means for the constructivist group is 10.28 while the posttest and pretest mean difference for the transmissive group is 7.82. The test for hypothesis one below will show if there is a significant difference in pretest and posttest scores of students' taught in the two learning environments.

Table 1. T-test summary table of students taught in Constructivist and transmissive learning environments

\begin{tabular}{|c|c|c|c|c|c|c|c|c|}
\hline Test & L.E & $\mathrm{N}$ & Mean & $\mathrm{SD}$ & Mean diff. & $\mathrm{df}$ & t-cal & t-cri \\
\hline Pre- test & $\begin{array}{l}\text { Const. } \\
\text { Tran. }\end{array}$ & $\begin{array}{l}122 \\
121\end{array}$ & $\begin{array}{l}14.32 \\
14.37\end{array}$ & $\begin{array}{l}3.97 \\
4.52 \\
\end{array}$ & 10.28 & 241 & 0.08 & 1.96 \\
\hline Post-test & $\begin{array}{l}\text { Const. } \\
\text { Trans }\end{array}$ & $\begin{array}{l}122 \\
121 \\
\end{array}$ & $\begin{array}{l}24.61 \\
22.19 \\
\end{array}$ & $\begin{array}{l}5.69 \\
4.74 \\
\end{array}$ & 7.82 & 241 & 3.58 & 1.96 \\
\hline
\end{tabular}




\subsection{Test for Hypothesis One}

Hypothesis one states that "there is no significant difference in achievement test of students taught basic science in a constructivist and in a transmissive learning environment".

The pretest scores shown in table 1 indicate that there is no significant difference in the academic achievement scores of students in the two groups. Also in table 1, the t-calculated value is 0.08 , which is lower than that of the $t$-table value of 1.96. This means no significant difference in the constructivist and transmissive learning environment in the pretest.

The posttest scores were significantly different as seen in table 1, because t-calculated value (3.58) is higher than the $\mathrm{t}$-critical value (1.96). Thus there is a significant difference in the academic achievement of basic science students taught in a constructivist learning environment and those taught in a transmissive learning environment in favour of the constructivist group.

\subsection{Research Question Two}

Is there any difference in basic science achievement test scores of high and low ability students exposed to a constructivist learning environment and those exposed to a transmissive learning environment?

The table 2 shows that the grand mean for the students in the different ability and groups on pretest of Basic science achievement is 14.84 , and the direction of gains in scores over grand means from the highest to the lowest is in this order: high transmissive (2.48) > high constructivist (2.31) > low transmissive $(-2.36)>$ low constructivist $(-2.43)$. The low constructivist group had the lowest pretest score below grand pretest mean.

The post-test grand mean is 24.16 and the direction of gains in scores over grand means from the highest to the lowest is in this order: high constructivist $(6.15)>$ high transmissive $(2.23)>$ low constructivist $(-3.64)>$ low transmissive (-4.75). Also the difference between posttest and pretest means of the high and low abilities clearly means learning environments had greatest impact on the high constructivist group followed by the high transmissive group. Learning environment had the least impact on the low transmissive group.

However the testing of hypothesis two below shows the test for significant difference in the post test means. This will further show which of the two learning environments favours both high and low ability groups.

\section{Test of hypothesis two:}

- Hypothesis two states that "there is no significant difference in achievement test of high ability and low ability students taught basic science in a constructivist and a transmissive learning environment".

Table 2. Showing pretest, posttest and grand means of high and low ability levels in both learning environments

\begin{tabular}{|c|c|c|c|c|c|c|c|c|}
\hline Groups & $\mathrm{N}$ & $\begin{array}{l}\text { Pretest } \\
\text { means }\end{array}$ & $\begin{array}{l}\text { Grand } \\
\text { mean }\end{array}$ & $\begin{array}{l}\text { Gains over } \\
\text { grand mean }\end{array}$ & $\begin{array}{l}\text { Posttest } \\
\text { Mean }\end{array}$ & $\begin{array}{l}\text { grand } \\
\text { mean }\end{array}$ & $\begin{array}{l}\text { Gains over } \\
\text { grand mean }\end{array}$ & $\begin{array}{c}\text { Diff. btw posttest and } \\
\text { pretest }\end{array}$ \\
\hline Ability*LE & & & \multirow{5}{*}{14.84} & & & \multirow{5}{*}{24.16} & & \\
\hline High constructivist & 26 & 17.15 & & 2.31 & 30.31 & & 6.15 & 13.16 \\
\hline Low constructivist & 44 & 12.41 & & $-2.43 * *$ & 20.52 & & $-3.64 *$ & 8.11 \\
\hline High transmissive & 28 & 17.32 & & 2.48 & 26.39 & & 2.23 & 9.07 \\
\hline Low transmissive & 48 & 12.48 & & $-2.36^{*}$ & 19.41 & & $-4.75 * *$ & 6.93 \\
\hline All High*Low Ability & & & \multirow{3}{*}{14.75} & & & \multirow{3}{*}{24.15} & & \\
\hline High & 54 & 17.02 & & 2.27 & 28.22 & & 4.07 & 11.20 \\
\hline Low & 92 & 12.47 & & $-2.28 *$ & 20.08 & & -4.07 & 7.61 \\
\hline
\end{tabular}

*scores below the grand mean, ${ }^{* *}$ lowest score below grand mean

Table 3. Showing t-test comparison of high and low ability students in the constructivist and transmissive learning environment

\begin{tabular}{|c|c|c|c|c|c|c|c|}
\hline L.E & Ability & $\mathrm{N}$ & Means & $\mathrm{Sd}$ & $\mathrm{df}$ & t-test & t-cri \\
\hline Const & $\begin{array}{l}\text { High } \\
\text { Low }\end{array}$ & $\begin{array}{l}26 \\
44 \\
\end{array}$ & $\begin{array}{l}30.31 \\
20.52\end{array}$ & $\begin{array}{l}4.91 \\
4.55 \\
\end{array}$ & 68 & 8.44 & 1.96 \\
\hline Trans & $\begin{array}{l}\text { High } \\
\text { Low }\end{array}$ & $\begin{array}{l}28 \\
48\end{array}$ & $\begin{array}{l}26.39 \\
19.41\end{array}$ & $\begin{array}{l}4.86 \\
3.76\end{array}$ & 74 & 6.99 & 1.96 \\
\hline $\begin{array}{l}\text { Const } \\
\text { Trans }\end{array}$ & $\begin{array}{l}\text { High } \\
\text { High }\end{array}$ & $\begin{array}{l}26 \\
28 \\
\end{array}$ & $\begin{array}{l}30.31 \\
26.39\end{array}$ & $\begin{array}{l}4.90 \\
4.86 \\
\end{array}$ & 52 & 2.94 & 2.02 \\
\hline $\begin{array}{l}\text { Const } \\
\text { Trans }\end{array}$ & $\begin{array}{l}\text { Low } \\
\text { Low }\end{array}$ & $\begin{array}{l}44 \\
48 \\
\end{array}$ & $\begin{array}{l}20.52 \\
19.41\end{array}$ & $\begin{array}{l}4.55 \\
3.76 \\
\end{array}$ & 90 & 1.27 & 1.96 \\
\hline
\end{tabular}


Where sd-standard deviation, md- mean difference

Test of hypothesis two shown in table 3 indicates the following:

- A significant difference in the mean achievement test between high and low ability students in the constructivist group.

- A significant difference in the mean achievement scores between high and low ability students in the transmissive group.

- A significant difference in the mean achievement scores between high ability constructivist and high ability transmissive group.

- $\quad$ No significant difference in mean achievement scores between low ability constructivist and low ability transmissive group.

Based on the test result above, the hypothesis two was accepted for the comparison of low abilities of the constructivist and transmissive paired groups since tcalculated value at 1.27 is less than the critical value. However for the other three paired groups, the hypothesis two was rejected on the ground that $\mathrm{t}$-calculated values of $\mathrm{t}=8.44 ; 6.99 ; 2.94$; are respectively greater than the $\mathrm{t}$-critical of 1.96 and 2.02. The result shows that the high abilities of both groups did better than the low abilities. However since the high constructivist did significantly better than the high transmissive $(\mathrm{t}=2.94)$, and the low constructivist did better than the low transmissive, we conclude that the constructivist environment is still preferred.

\section{Discussion of Results}

This study examined whether there were differences in academic achievement and ability levels among junior secondary school students taught basic science in two teacher-created learning environments- the constructivist learning environment and the transmissive learning environments. It also examined which of the learning environments favored either the high or low ability groups.

This study emphasized that the learning environment created by the teachers can affect students' academic achievement. And the degrees of significant effect were seen after the test of the hypotheses. It was discovered that there was a significant difference in the academic achievement between students taught in the Constructivist learning environment and those taught in the transmissive learning environment in favour of the constructivist group. Although it was also discovered that both learning environments favoured the high ability groups, however the low ability constructivist group did better than the low transmissive group. It is therefore concluded that the constructivist environment should be created by basic science teachers taking note of the gap between the high and low ability students. Although this gap was not taken care of by both learning environment, more research can be carried out to find out how this learning gap can be closed using the constructivist environment. This finding is in agreement with researches carried out by other researchers that the nature of the learning environment created by teachers can affect the academic achievement of students $(29$-32). Results of this study also showed that there was a significant increase in academic performance of students taught in the constructivist learning environment over those taught in the traditional learning environment (33-36). Owoso (29) found out that students taught auto-mechanics using the constructivist instructional approach performed significantly better in achievement test than those taught using the lecture method. It can therefore be concluded that the effect of the constructivist learning environment was the reason for the students performing better. However contrary to the findings of this study some researchers found out that that there were no significant differences in academic achievement of students taught in the constructivist and traditional learning environments $(8,22,37)$.

On academic ability of students, results shows that a significant difference for high and low ability students in both the Constructivist group and for high and low ability students in the transmissive learning environment group. This is in line with other researchers who found out that irrespective of the learning environment, the high ability students will do better than the low ability students $(8,35$, 40). According to Igwebuike (8) student ability levels can be used to predict student cognitive achievement from instruction hence ability levels is a reasonable predictor of cognitive learning outcome as is the case in this research. Another interesting finding is that there was a significant difference between high ability constructivist and the high ability transmissive group in favor of the constructivist group. Also, no significant difference was found between the low-constructivist group and the low ability transmissive group. Contrary to this finding, other results of previous studies show a significant difference between low constructivist group and low transmissive group in favor of the constructivist group $(24,35)$.

\section{Conclusion and Recommendations}

The result of this study has shown that the creation of a student friendly environment like the constructivist learning environment can enhance the academic performance of students, and high ability students in particular, in Basic science. Teachers also should consider the low ability students and ensure they are given extra tutorials to reduce the gap existing between the high and low ability as indicated in this study.

This study has implications for teachers that better and more matured relationship between science teachers and their students and between students and their fellow students can be found in a constructivist learning environment giving room for students to discuss freely with their teacher and with their fellow students thereby eradicating the student-teacher friction and 
student-passiveness that can be found in a traditional science classroom. It also has implications for more researches to be carried out on ways to reduce the gap existing between the high and low ability students in a constructivist class.

In conclusion this research rejected the two null hypotheses and found that there were significant differences in basic science achievements scores of students taught in a constructivist and transmissive learning environment. It also found that in both learning environments, the high abilities did better than the low. It is therefore recommended that the constructivist learning environment should be created by basic science teachers while giving extra consideration and attention to the low ability students. It is also recommended that more researches should be carried out to find out possible ways to reduce the gaps between high and low ability students in a constructivist environment.

\section{REFERENCES}

[1] Federal Government of Nigeria. National Policy on Education. Lagos. NERDC. (2004).

[2] B. Fraser, H. Walberg. Educational environment; evaluation, antecedents and consequences. Oxford. Pergamum Press. 1991.

[3] H.S. Thorp, R.L. Burden, B. Fraser. Assessing and Improving Classroom environment. Science Education notes. 75 (272) (1994).

[4] A. Hofstein, T.L. Nahum, R. Shore. Assessment of learning environment of enquiry type laboratories in high school chemistry. Learning environment research (4) 193-207. (2001).

[5] B.J. Fraser. Science learning environment; Assessment, effects and determinants. Retrieved from. http://education.curtin.edu.au/iier/qjer/qjer 18/editorial: 8-2. Html (2004).

[6] T. Wubbels, M. Brekelmans. The teacher-factor in the social climate of the classroom in B. Fraser \& Tobin (Ed). International handbook of science education pg. 565-580. Dordrecht, the Netherlands Kluwer. (1987).

[7] T. Wubbel, J. Levy. A comparison of interpersonal behaviour of Dutch and American teachers. International journal of international relations 15(1)1-18 (1991).

[8] T. Igwebuike. The effect of constructivist learning environment on students' achievement in integrated-science. Unpublished Ph.D Thesis. University of Benin. Nigeria (2000).

[9] S. Kaufman. Improving students' relationship with teachers' to provide essential supports for learning. American Psychological Association.

http://apa.org/education/k12/relationships.aspx. (2012).

[10] P.C. Taylor, B.J. Fraser, D.L. Fisher. Monitoring Constructivist classroom learning environments. International Journal of Educational Research 27 (293-302).
(1997).

[11] P. Sebella. Using action research to promote constructivist classroom learning environments in mathematics in South Africa. South Africa Journal of Education 24(4)245-253. (2004).

[12] G. Banerjee. Blended Environments; Learning Effectiveness and Students Satisfaction at a Small College in Transition. The Sloan Consortium. 15 (2) Feb 2011

[13] B.J. Fraser, Y.N Chinoh. Classroom environment, selfesteem, achievement and attitude in Geography and Mathematics in Singapore. A paper presented at the annual meeting of American Educational research Associations, New Orleans. April 2000.

[14] S.C. Goh, B.J. Fraser. Teacher Interpersonal behaviour, classroom Environment and Student outcome in physic and math in Singapore. Learning Environment research vol.1 199-229(2000).

[15] M. Hanrahan. The effects of learning environment factors on students' motivation and learning. International Journal of Science Education 20(6) 737-753. (1998).

[16] M. A Hussian, M. Z. Igbal, S. M. Akhtar. Technology based learning environment and student achievement in English as a foreign language in Pakistan. World Academy of Science Engineering and Technology 61. 2010

[17] C.J. Mc Robbie, W.M. Roth, K.B. Lucus, Multiple learning environments in a physics classroom. International journal of educational research 27(333-342)1997.

[18] L. Para. Overview of Environmental Factors That Affect Teaching and Learning/.http://paraelink.org.2004

[19] A.F. Wong, B.J. Fraser. Gender differences in the perception of chemistry laboratory classroom environments. Queensland journal of educational research 18(2)164-182. 2010.

[20] M. Yilmaz-Soylu, B. Akkoyunlu. The effects of learning styles on achievement in different learning environments. The Turkish online Journal of Educational Technology (T.O.J.E.T) 8(4) 43-50. 2009.

[21] S.L. Akinseide. Principles and Methods of Instruction in Technology Education. Ibadan. Kenny Ventures. 1998.

[22] K.O. Igboko, O.T Ibeneme, Effects of Some cognitive constructivism instructional approaches on students' achievement and retention in the study of introductory technology in Nigeria. Journal of Science Teachers Association of Nigeria, 41(1, 2). (2005).

[23] E.E. Kpeke, L. Osho. Approaches, Methods strategies and techniques of teaching. In Inomiesa E.A \& Osakwe E.O. Principles and practices of teaching. Warri. About Publishers. 1997.

[24] J.N. Okoli. Effects of investigative laboratory approach and expository methods on acquisition of science process skills by biology students of different levels of scientific literacy. JSTAN 41(1\&2), Dec 2006.

[25] R. Atomatofa. Effects of Inquiry, Discussion and Lecture Methods on Students' Academic Achievement in Integrated-Science. Unpublished M.Ed Thesis. Delta State University, Abraka. 2007. 
[26] J.C. Turner, C Midgley, M. Gheen, E. Anderman, Y. Kang, H. Patrick. The classroom environments and Students reports of avoidance strategies in mathematics. A Multimedia Study. Journal of Educational Psychology 94(1)88-106. 2002

[27] O.P. Ajaja. An Evaluation of Differential Effectiveness of Ausubel, Bruner and Karplus methods of Teaching Biology in Nigerian Secondary Schools. Unpublished Ph.D Thesis, University of Benin. 1998.

[28] J.M. Aldridge, B. J. Fraser R. Laugksch. Relationship between School-level and Classroom-level Environment in secondary schools in South Africa. South Africa Journal of Education. 31:127-144. 2011

[29] J Owoso. Effects of the constructivist instructional approach on achievement and retention of auto mechanics students in technical colleges. University of Nigeria, Nsukka PhD.2009

[30] P. Agomuoh. Effect of Prior knowledge, Exploration, Discussion, Dissatisfaction with prior knowledge and application and the learning cycle, constructivist instructional models on students' conceptual change and retention in physics. Abstracts of Theses, University of Nigeria. Nsukka. 2005-2010.

[31] I.Ogundola, A. Popoola J. Oke.. Effect of constructivism instructional approach on teaching practical skills to mechanical related trade students in western Nigeria technical colleges. International NGO Journal, 5(3)59-64. 2010
[32] N. Etuk, G. Etuk, E. Etudor-Eyo, J. Samuel Constructivist Instructional Strategy and Pupils Achievement and Attitude towards Primary Science. Bulgarian Journal of Science and Education Policy (BJSEP) 5(1) 2011.

[33] A.R. Ogunkunle, S.T. Gbamanja. Constructivism: An instructional strategy for sustaining students' self-concept in secondary school mathematics. Journal of Science Teachers Association of Nigeria, 41(1,2). Dec 2006

[34] C. Nwagbo, \& C. Obiekwe. Effects of constructivist instructional approach on students' achievement on basic ecological concepts in biology. Journal of Science Teachers Association of Nigeria (JSTAN) 45(1\&2) April \& Sept, 2010

[35] C.C. Ogbonna. Effects of constructivists instructional approach on senior secondary school students and interest in Mathematics. Unpublished Ph.D thesis. University of Nigeria Nsukka. 2003.

[36] P. Puacharearn, D. Fisher. The effectiveness of cooperative learning integrated with constructivist teaching on improving learning environments in THAI secondary school science classrooms; a paper presented at IASCE conference, Singapore. June 21-25 2004.

[37] M.A. Andrusyszn. The Effect of the Lecture Discussion teaching method with or without audio-visual augmentation on immediate and retention learning. Nurse Education Today. (10) 172-180. 2004 